\title{
The importance of perceived risk in destination image and its effects on behavioral intention
} Diana Martín-Azami* Francisco Javier Ramos-Real**

Universidad de La Laguna (España)

\begin{abstract}
In this work we analyze the process by which the decision of visiting a destination is the result of evaluating its image, being risk an important factor that has an effect on the destination's image. Taking the previous literature into account, and considering the multidimensional character of these two constructs, we propose a classification of the different approaches that link risk and image with behavioral intention. This work, without being an exhaustive review of the literature, clarifies the state in which the study of this subject is found and gives guidance to the researchers in this field.
\end{abstract}

Keywords: Perceived risk; Perceived destination image; Tourist behavioral intention.

La importancia del riesgo percibido en la imagen de destino y sus efectos sobre la intención de comportamiento

Resumen: En este trabajo analizamos el proceso mediante el cual la decisión de visitar un destino es el resultado de evaluar su imagen, siendo el riesgo un factor importante que influye en la imagen del destino. Teniendo en cuenta la literatura previa, y considerando el carácter multidimensional de estos dos constructos, proponemos una clasificación de los diferentes enfoques que vinculan el riesgo y la imagen con la intención del comportamiento. Este trabajo, sin ser una revisión exhaustiva de la literatura, aclara el estado en el que se encuentra el estudio de este tema y brinda orientación a los investigadores en este campo.

Palabras clave: Riesgo percibido; Imagen percibida del destino; Intención del turista.

\section{Introduction}

International tourism is facing a troubled and hostile period, notable for numerous incidents such as the 9/11 attacks in 2001 in the United States (11S), the Severe Acute Respiratory Syndrome (SARS) in 2003, the Katrina hurricane in 2005, and more recently, the attacks in Barcelona (2017), to name a few. These events spread around the world in no time in the age of information and communication technology. Such dramatic events, as many authors point out, can cause a negative impact on the image of tourist destinations (Alvarez \& Campo, 2014; Huang, Tseng \& Yiap, 2013) resulting in a drastic drop in the number of visits.

As Gartner (1994) points out, news broadcasts have a significant influence on the development of a destination's image. The broadcasting of information on political instability, natural disasters or other threats to a destination contributes to its image formation thus producing effects on the tourist's behavior (Law, 2006; Kozak, Crotts, \& Law, 2007). People tend to avoid those places considered dangerous while peace, tranquility and safety are prerequisites to attract visitors (Sönmez, 1998). In other words, the decision of visiting a destination is the result of evaluating its image, being risk an important factor that has an effect precisely on the destination's image.

There are many works in the literature that analyze the relation between risk and behavior intention (Yang \& Nair, 2015), and between destination image and the latter (Chon, 1990; Pike, 2002). Perpiña, Camprubí and Prats (2017) point out that destination image is not the only variable that determines the tourist's choice, emphasizing the influence of perceived risk. The authors highlight that "prominent

\footnotetext{
* Universidad de La Laguna (España); E-mail: dimartin@ull.es

** Universidad de La Laguna (España); E-mail: frramos@ull.es
} 
scholars support the call to interrelate risk perception and destination image literature" in order to benefit both theory and practice within the field of tourist choice (Chew \& Jahari, 2014; Lepp, Gibson, \& Lane, 2011; Qi, Gibson, \& Zhang, 2009; Sönmez, 1998)" (p.2). Moreover, the identification of risk factors contributes to a better understanding of the destination's image and makes it possible to understand its impact on the tourist's behavior" (Hamouda \& Yacoub, 2018: 69).

Ruan, Li and Liu (2017) suggest that when tourists consider the perceived risk in the decision to visit a destination, it becomes a determinant of its image. Perceived risk and destination image are multidimensional concepts. The use of theoretical and empirical models to explain the interrelations between the components of both constructs is key to understanding the destination image formation process and tourist behavior. In summary, the capacity of a model to explain behavioral intention increases when interrelating perceived risk and destination image. Besides, the results of the studies that integrate risk and image allow obtaining vital information to manage tourist destinations and manage their crises.

Bearing this in mind, the aim of this paper is to analyse the influence of risk on destination image so that a classification of the different approaches that link these two constructs with behavioral intention can be proposed. Starting from this analysis, and taking the dimensions that make up risk and image into consideration, we identify three approaches: isolated, intrinsic and integrative. The latter is based on the recognition of the participation of risk in the destination image formation process. Although it offers more information to explain the choice of a destination, there are few works based on this approach. Therefore, a development of this interesting field of research is pending. The usefulness of this work is twofold. Firstly, without being an exhaustive review of the literature, it clarifies the current state of the study of this subject. Second, it gives guidance on the direction of the efforts to be made by the researchers in this field. What is more, this information can be of great use for marketers and policy makers in the management of tourist destinations.

In this article, the concepts of perceived risk and destination image will be analysed through different contributions from the literature. Similarly, the way in which different studies determine the dimensions that make up both concepts as well as the interrelations between them will also be analysed. This review will be the foundation upon which our new classification system will be built. This work is structured as follows. First, the notions of perceived risk and destination image will be analysed. In particular, we will focus on the participation of risk in the destination image formation process. Considering contributions from the literature, a classification of the different approaches that link these constructs with behavioral intention will be proposed. Finally, the conclusions of the study will be established.

\section{Perceived risk in tourism}

The way in which risk is conceptualized and measured in tourism has been nourished from previous contributions in the marketing field. Most works deal with perceived risk rather than actual risk because, regardless of the existence or non-existence of an actual risk (objective) and its magnitude, consumers are preoccupied with the risk they are able to perceive. Bauer (1960) defines, for the first time in the marketing field, the concept of perceived risk as the consumer's perception of the consequences derived from his actions which cannot be foreseen with certainty, and some of which are likely to be unpleasant.

With time, this seminal definition has been reviewed. Thus, perceived risk is usually defined in terms of the consumers' perceptions about uncertainty and the magnitude of possible unfavorable consequences when purchasing a product or service (Dowling \& Staelin, 1994). The assessment of risk intensity will have unequal effects on the consumer's behavior. Thus, risk will be tolerable as long as both the level of uncertainty and the probability of a negative result in the purchase are low (Ross, 1975). However, if the perception of danger goes beyond an acceptable threshold, consumers will feel vulnerable and, consequently, will be dissuaded from their intention of buying. Risk is, therefore, avoidable in many cases.

In the case of tourism, a series of specifications must be borne in mind. The complex nature of the tourist product (intangible, heterogeneous, inseparable and perishable) makes it unable to be experienced until after its purchase (Fakeye \& Crompton, 1991), thus often only competing via images (Pike \& Ryan, 2004). These unique features, in addition to the high cost of vacation travels (both in economic and time terms), make the tourist experience a risk in itself (Gitelson \& Crompton, 1983). In the tourism field there is also a preponderance of works dealing with perceived risk rather than actual risk (Quintal, Lee \& Soutar, 2010). Once to this point, perceived risk in tourism can be defined as “a consumer's [tourist's] perception of the overall negativity of a course of action based upon an assessment of the possible negative outcomes and the likelihood that those outcomes will occur" (Mowen \& Minor, 1998: 176). 
According to this notion, the tourist evaluates the possibility of an action, exposing himself to misfortune, threats, losses, or a lack of safety in the process of travelling or at a destination (Reisinger \& Mavondo, 2005; Sönmez \& Graefe, 1998a; Tsaur, Tzeng, \& Wang, 1997).

\section{Risk dimensions}

The identification of the risk dimensions is a key task in the definition of the construct. It is also essential in order for destination managers to guide the formulation of strategies, as it makes it possible to recognize the types of risk which concern tourists the most. Research on consumer general behavior has left a mark again on tourism in a way that risk dimensions have adapted to the tourist experience. In this sense, based on the marketing literature, up to seven theoretical dimensions of risk (Cheron \& Ritchie, 1982; Jacoby \& Kaplan, 1972; Kaplan, Szybillo, \& Jacoby, 1974; Roselius, 1971; Ross, 1975; Schiffman \& Kanuk, 1991; Stone \& Grønhaug, 1993) are identified in tourism, defined as the tourist preoccupation because the product (service, destination, activity, etc.) might: (1) not have a good quality/price ratio (financial risk), (2) not be as good as expected (functional risk), (3) harm your health (physical risk), (4) damage your self-esteem (psychological risk), (5) be disapproved by reference groups (social risk), (6) not be satisfying (satisfaction risk) and (7) mean a waste of time (time risk).

Roehl and Fesenmaier (1992) use this theoretical classification of risk dimensions in the empirical study of tourist risk perceptions in pleasure travels. Their work confirms that tourists perceive different risks according to the place and the phenomenon of study, which hinders the generalization of results from one destination to another. For this reason, the authors advise about the utilization of measures that are appropriate to the context of interest and related to the research. However, their work has been criticized due to each theoretical dimension of risk being assessed with only one question, thus being unable to collect the amplitude of the concept. Other proposals overcome this pitfall by measuring perceived risk using multi-attribute scales, where each risk dimension consists of several questions (Fuchs \& Reichel, 2006).

The adaptation of the theoretical dimensions to each destination and according to the object of study has become patently clear in numerous pieces of empirical research. Below, we mention only some examples of risk dimensions and/or attributes included in response to the necessity of adapting scales in different studies: political instability (Sönmez \& Graefe, 1998a, 1998b); hygiene (Maser \& Weiermair, 1998); political/ religious dogmas (Lepp \& Gibson, 2003); crime (Floyd, Gibson, Pennington-Gray \& Thapa, 2004); terrorism (Reisinger \& Mavondo, 2005); environmental (Dolnicar, 2005); induced by man (Fuchs \& Reichel, 2006, 2011); overcrowding (Reichel, Fuchs, \& Uriely, 2007); infectious diseases (Kozak et al., 2007); transportation performance (Simpson \& Siguaw, 2008); violence (Qi, Gibson \& Zhang, 2009); deterioration of tourist attractions (Rittichainuwat \& Chakraborty, 2009); mass (Fuchs, 2013) or, expectations (Adam, 2015).

\section{Perceived destination image}

The image of a destination is a mental representation of such destination (even if it has not been visited and/or exposed to commercial information), which is created from its assessment (Echtner \& Ritchie, 1991). By understanding this concept, the formulation and implementation of strategies to improve the image of the destination will be easier for marketers and decision makers.

As happens with the notion of perceived risk, the use of the term perceived image is more widespread, as each individual creates his own image of the destination. There is no agreement when it comes to conceptualizing the image of a tourist destination (Gartner, 1994). According to how it is defined, from one to three dimensions or components can be identified: cognitive, affective and conative which, in this order, receive a higher to lower theoretical support. The recognition of different destination image dimensions, overshadowing the idea of the existence of a single global image, allows the introduction of more effective promotional strategies (Ahmed, 1996).

\section{Image dimensions}

The majority of research has focused on the cognitive dimension when explaining the concept of destination image. According to this dimension, image consists of a set of impressions, perceptions, ideas, beliefs, knowledge or subjective interpretation regarding the characteristics or attributes of the destination (Bigné, Sánchez, \& Sánchez, 2001; Crompton, 1979; Hui \& Wan, 2003; Hunt, 1975). With respect to the affective dimension, there is an upward trend in its inclusion as a component of destination image. This dimension refers to the feelings or emotions evoked by the destination (Baloglu \& Brinberg, 1997; Beerli \& Martín, 2004a; Chon, 1990; Xu, Chan, \& Pratt, 2017; Zhang, Fu, Cai \& Lu, 2014). 
Lastly, the conative dimension is linked to the predisposition to action, intention, will, or probability of initiating an action (Agapito, Oom Do Valle \& da Costa Mendes, 2013; Dann, 1996; Gartner, 1994; Pike \& Ryan, 2004; Stylos, Vassiliadis, Bellou \& Andronikidis, 2017). This dimension takes place after the assessment (positive or negative) of the cognitive and affective dimensions, and can be materialized into action, or not. The incorporation of the conative dimension as a facet of destination image is more recent and, in fact, less recognized. Following Pike \& Ryan (2004) "The conative image is analogous to behavior since it is the intent or action component [...] Conation may be considered as the likelihood of visiting a destination within a certain time period" (p.334). It is more commonly used as an independent construct named behavioral intention (Bigné et al., 2001; Chen \& Tsai, 2007; Prayag, 2009; Wang \& Hsu, 2010) rather than an integral dimension of perceived image.

Although there are few studies on the weight of the affective dimension on destination image, and the relation between the cognitive and affective dimensions (San Martín \& Rodríguez del Bosque, 2008), Baloglu and McCleary (1999) establish that the coexistence of both dimensions determines the global image of a destination. The authors develop a model (widely accepted) of destination image formation that reflects this relation. In a context of urban destinations, Olague, Flores \& Garza (2017) find evidence that the cognitive dimension precedes the affective dimension.

With regard to the measurement of perceived image, the preference for scales observed in empirical works is as follows. On the one hand, the affective dimension is generally measured by using the semantic differential scale by Russell and Pratt (1980), in which the following emotions are compared: arousing/sleepy, pleasant/unpleasant, distressing/relaxing, and exciting/gloomy. On the other hand, regarding the measurement of the cognitive dimension, the use of Likert-type scales is common practice, where the tourist shows his degree of agreement with a series of statements about the attributes of the destination, such as climate, price, accommodation, gastronomy, etc. (Gallarza, Saura, \& García, 2002). ${ }^{1}$ Measurement scales vary from one work to another in the same way as happens with risk, due to the necessity of adapting both to destination and the purpose of the study.

\section{Perceived risk in destination image formation process}

We have previously highlighted that when tourists take perceived risk into account in their choice, aspects such as crime, strikes in the sector or political instability (among others) contribute to form an image of the destination. But, how does this process of image formation take place? To understand the relation between risk and image, it is necessary to explain the way in which risk participates in the destination image formation process. This process constitutes one of the main focal points in the study of image, as it means the recognition of the different factors that condition destination image (Gartner, 1989). The identification of these factors and the understanding of their influence favor the effectiveness of the efforts to create an attractive image (Fakeye \& Crompton, 1991). The destination image formation process is represented in figure 1.

Figure 1: Destination image formation process

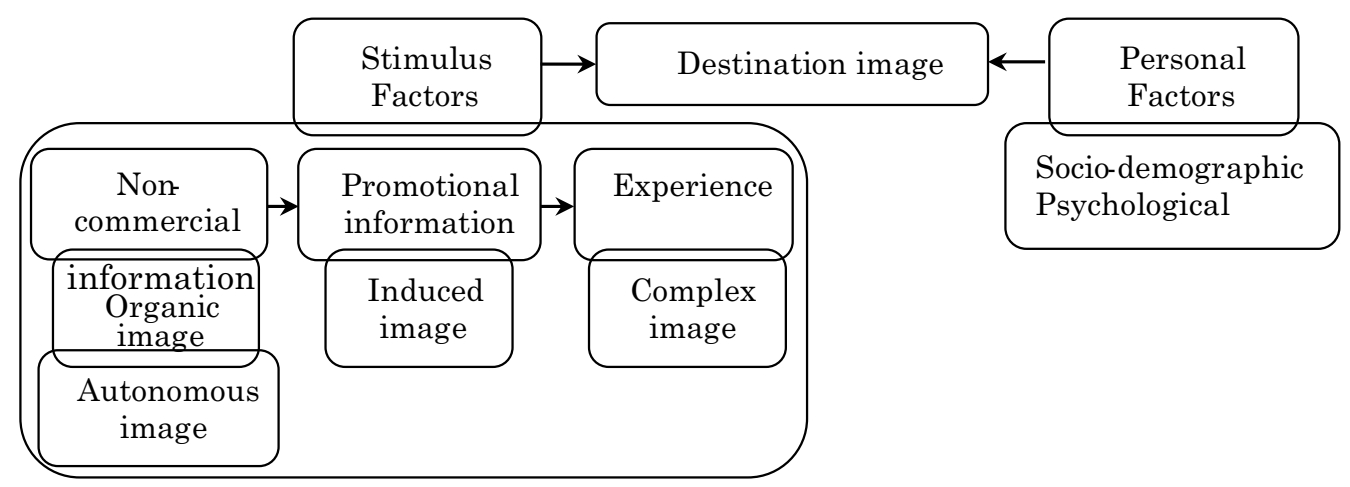

Source: Own elaboration based on literature 
Image formation factors can be classified into two categories, personal (socio-demographic and psychological), and stimulus (sources of information including experience). Perceptions of image are internalized through the personal factors (Beerli \& Martín, 2004b). Hence the fact that image is a relative or subjective construction, that is, different for each individual, unique or personal (Gallarza et al., 2002). On the other hand, stimulus factors converge in the image formation process through a series of stages causing, in a sequential order, three types of images: organic, induced and complex (Fakeye \& Crompton, 1991; Gunn, 1988). First, the organic image is formed from non-commercial sources of communication (opinions of friends and relatives, books, films, news in the media, etc.). Then, the induced image is formed via additional information of a promotional nature (travel guides, brochures, travel agents, tour operators, etc.). Finally, if the destination is visited, experience will constitute the complex image.

Regarding the importance and weight of image formation factors, clear differences are found. Induced image formation factors have little credibility, but they are essential in order to give renown to a destination (Woodside \& Lysonsky, 1989), especially if it has not yet been visited. On the other hand, organic image formation factors give legitimacy to the information, thus having more credibility and also being the most utilized sources (Gitelson \& Crompton, 1983). When the source of information is based on experience, a more realistic (Gartner \& Hunt, 1987) and differentiated image is formed in comparison with that of those who have not yet visited the destination (Milman \& Pizam, 1995).

According to the destination image formation process described above, perceived risk participates in such process as a stimulus factor. Normally, the main sources of information about threats to destinations are news being broadcast by the media. Gartner (1994) mentions the impact of these sources on image formation due to their significance, considering them autonomous image formation agents implicit in the organic image (see figure 1). In the author's own words,

Generally destination area promoters have no control over what appears in a news story and the projected image is based on someone else's interpretation for what is happening in the area. News reporting, because of its supposedly unbiased presentation, is assumed to have significant impacts on tourism image development. If the event reported is of major importance the opportunity for image change, in a relatively short period of time, is present. (Gartner, 1994: 201)

Although the broadcasting of positive news about the destination causes favorable effects on the autonomous destination image, the broadcasting of contingencies may harm (seriously, in some cases) such image. Thus, the way in which the tourist perceives risk linked to negative events coming from the media (which is sometimes the only source of information available about the destination) has a significant weight on image. Therefore, the recognition of risk as a stimulus factor in the destination image formation process helps marketers to direct their actions towards minimizing its negative impact.

\section{Classification of the approaches that link risk, image and tourist behavioral intention}

Once the connection between risk and image is explained, the influence of this interrelation on tourist behavioral intention requires a deeper analysis. This is key in order for the destination management to avoid the effects of possible negative events. In spite of its importance, there is little literature explaining this interrelation. The aim of this section is to show this gap and encourage research in this field by proposing an innovative classification based on the way in which the relations between these three constructs have been addressed. This classification distinguishes three approaches: isolated, intrinsic and integrative. Heretofore, most works in the literature deal with the first two categories. The first two approaches will be analyzed without presenting an extensive revision since this task has already been carried out by other authors. However, bibliographic references are provided so that it can be investigated in this regard. However, the scarcity of studies that analyze the relationship between perceived risk, destination image and intention to visit is glaring (Hamouda \& Yacoub, 2018; Lehto, Douglas \& Park, 2008). The integrative approach has received little attention and the works found are recent. For this reason, more attention is devoted. In addition, we believe that it is an interesting line of research that could give promising results. 


\subsection{Isolated, intrinsic and integrative approaches}

\section{Isolated approach}

The isolated approach separates the study of risk from that of image, thus establishing a direct relation between each construct and tourist behavior (hypotheses $h a$ and $h b$ in figure 2). The results of the analyses show that both risk and image have an influence on the destination choice process.

\section{Risk perception on behavioral intention}

In an extensive review of the risk literature, Yang and Nair (2015) highlight that the effects of risk perception on behavioral intention is one of the main focal points of the selected bibliography. ${ }^{2}$ The main conclusion to be drawn from these works is that risk perception has the capacity of inhibiting the travel (Um \& Crompton, 1992). The study of the influence of risk perception on behavioural intention allows recognising those issues that worry tourists the most in their journeys (e.g. infections, wars, natural disasters, etc.), and consequently, help establish policies to minimize them.

The empirical works carried out in different geographical contexts confirm that most travellers are prone to change their travel plans if they perceive a high exposure to risk (Kozak et al., 2007; Sönmez \& Graefe, 1998a). Law (2006) found that Asian travellers were more likely than western tourists to change their travel plans due to their greater sensitivity to risk. Floyd et al. (2004) highlighted how the tourism industry was deeply affected after 9-11. Qi et al. (2009) found that the intention of attending the Beijing Olympic Games was significantly conditioned by the perception of violence and socio-psychological risk. The main limitation of this approach is that it does not consider the impact of risk on destination image, and therefore, it does not provide the necessary information to fix the image attributes that have been damaged by perceived risks.

\section{Image perception on behavioral intention}

Within the image field, the effects of image perception on behavioral intention are also one of the most relevant and popular topics among researchers and professionals (Chon, 1990; Tasci, Gartner \& Tamer Cavusgil, 2007). Other reviews of the literature such as Pike (2002) or Tasci \& Gartner (2007) show that the main interest of the works lie in knowing the effects of destination image on the visits. ${ }^{3}$ An important result from these works shows that a distorted image could hinder the potential development of a destination. The results of the empirical works show the influence of image on tourist behaviour (Schroeder, 1996; Hallmann, Zehrer \& Müller, 2013). Bigné, Sánchez and Sanz (2009) confirmed for a renowned sun-and-sand destination (Peñíscola, Spain) that the image turned out to be a significant antecedent to the visit and its recommendation. The work of Phillips and Jang (2010) revealed that the relation between image and behavioural intention varies between the tourists that visited the destination and those who did not.

Understanding the relationship between destination image and behavioural intention may be useful to recognise those image attributes that should be improved in order to have an influence on visit intention and recommendation. The diagnosis of strengths and weaknesses of destination image is useful in order to make specific changes in the destination as well as in its commercialisation (Goodrich, 1978). Nevertheless, this approach overlooks the possible factors of image formation linked with perceived risk that may be damaging the destination's image.

\section{Intrinsic approach}

In the intrinsic approach, risk is considered to be implicit in image. Thus, it is not treated as a construct but rather as an attribute of image. In this approach, it is common practice to include one or several items regarding the safety of the place in the destination image questionnaires (Alvarez \& Campo, 2014; Gartner \& Shen, 1992; Sönmez \& Sirakaya, 2002). According to this approach, there is a direct relation between image and tourist behavior (hypothesis $h c$ in figure 2). That is, it matches the causal relation expressed by hypothesis $h b$ of the isolated approach (in figure 2), but incorporating issues relative to risk or safety of the destination into the measurement of destination image. A remarkable outcome from most works is that risk becomes a relevant attribute in the valuation of image and, therefore, in tourist behavior.

Although risk perception and destination have been considered as separate construction in tourism research (Perpiña et al., 2017), we find numerous works in the intrinsic approach. We will mention some of these works, identifying the attribute associated with perceived risk they use in the measurement of destination image: Ross (1993) includes the safety/environment item; Chen \& Kerstetter (1999) introduce the item lack of crime/safe and, Chen \& Hsu (2000) incorporate the item safe place. For their part, Rittichainuwat, $\mathrm{Qu}$ and Brown (2001) identify one dimension relating to perceived risk that they label as "safe travel destination" after conducting a factorial analysis. 
The results of the empirical works show the influence of the image on the tourist's choice and, specifically of the "safety/safe" attribute of the destination's image (Gibson et al., 2008; Lin, Wu \& Chang, 2006; Rittichainuwat et al., 2001). The applications of the intrinsic approach have demonstrated the importance of adding attributes related to the general safety of the destination to the image assessment. However, this approach does not allow determining the specific threats (e.g. illnesses, conflicts, pollution, etc.) that damage the destination's safety image. Accordingly, destination promoters do not have the necessary information to put together actions to mitigate such threats or specific risks.

As we will see below, the integrative approach overcomes the limitations found in the previous approaches (isolated and intrinsic). In recent years, a series of empirical works within this new approach have provided a number of encouraging contributions in this field of study.

\section{Integrative approach}

In the integrative approach, the connection between risk and image, as mentioned above, is explained by the participation of risk in the destination image formation process as a stimulus factor. Thus, this approach examines the relation between perceived risk and destination image as distinctive constructs, and its effects on behavior intention within a single study. This new way of considering perceived risk together with destination image, adds valuable information to understand the tourist's behavior.

\section{Figure 2: Approaches for the analysis of the influence of risk and image on tourist behavior}

\begin{tabular}{|c|c|c|}
\hline Authors** & Approaches & Relationships between constructs \\
\hline $1,3,4,15,18,20$ & Isolated & \\
\hline $5,10,11,13,16$ & & mag \\
\hline $\begin{array}{l}2,6,7,8,9,12,14,17 \\
19\end{array}$ & Intrinsic & \\
\hline $21,22,23,24,25,26$ & Integrative & \\
\hline
\end{tabular}

* In the integrative approach, risk and image interchange the following roles: the independent (hypothesis $h d$ ), mediating (hypothesis he) and moderating (hypotheses $h f$ and $h g$ )

** 1. Goodrich (1978); 2. Ross (1993); 3. Schroeder (1996); 4. Court and Lupton (1997); 5. Sönmez and Graefe (1998a); 6. Chen and Kerstetter (1999); 7. Chen and Hsu (2000); 8. Rittichainuwat et al. (2001); 9. Sönmez and Sirakaya (2002); 10. Floyd et al. (2004); 11. Law (2006); 12. Lin et al. (2006); 13 Kozak et al. (2007); 14.Gibson et al. (2008); 15. Bigné et al. (2009); 16. Qi et al. (2009); 17. Chen and Funk (2010); 18. Phillips and Jang (2010); 19. Ramkissoon, Uysal and Brown (2011); 20. Hallmann et al. (2013); 21.Noh and Vogt (2013); 22. Tavitiyaman and Qu (2013); 23. Chew and Jahari (2014); 24. Wang (2015); 25. Kani et al. (2017); 26. Hamouda and Yacoub (2018).

Source: Own elaboration based on literature 
The following section describes the most relevant characteristics of the empirical works that are classified within the integrative approach. It is necessary to point out that there are other works (besides those indicated in table 1) that analyze the relationship between risk and image but, since they do not include in the model their influence on behavioral intention (e.g., Ruan et al., 2017), they are not considered to be part of the integrative approach.

\subsection{The integrative approach}

So far as is known, works explaining the relation among risk, image and behavioral intention, do so through several alternative causal models where behavioral intention is always the dependent variable. Nevertheless, risk and image interchange the following roles: the independent (hypothesis $h d$ in figure 2), mediating (hypothesis $h e$ in figure 2 ) and moderating (hypotheses $h f$ and $h g$ in figure 2 ) variables. ${ }^{4}$ As shown in table 1, there are works that incorporate, apart from risk and image, other variables (motivations, cultural values, overall satisfaction, etc.) to explain tourist behavior. The characteristics and main results of the works based on the integrative approach are commented next. The most noteworthy aspects are summarized in table 1 . In most articles, the image acts as a mediator in the models. Also, it is worth noting the attempts to incorporate the cognitive and affective components of the destination image to evaluate if there are differentiated effects depending on the component. On the other hand, the perceived risk usually precedes the image.

\section{Table 1: Integrative approach works characteristics}

\begin{tabular}{|l|l|l|l|l|}
\hline \multicolumn{1}{|c|}{ Authors } & \multicolumn{1}{|c|}{$\begin{array}{c}\text { Perceived } \\
\text { risk role }\end{array}$} & $\begin{array}{l}\text { Destination } \\
\text { image role }\end{array}$ & \multicolumn{1}{c|}{$\begin{array}{c}\text { Dependent } \\
\text { variable }\end{array}$} & Other variables and role \\
\hline $\begin{array}{l}\text { Hamouda and } \\
\text { Yacoub (2018) }\end{array}$ & Independent & Mediator & Intention to visit & $\begin{array}{l}\text { Electronic word of mouth } \\
\text { - eWOM - (independent), } \\
\text { motivations (independent) }\end{array}$ \\
\hline Wang (2017) & Independent & Mediator & $\begin{array}{l}\text { Behavioral } \\
\text { intention }\end{array}$ & No \\
\hline Kani et al. (2017) & Moderator & Mediator & Revisit intention & $\begin{array}{l}\text { Cultural values } \\
\text { (independent), destination } \\
\text { source credibility } \\
\text { (independent), destination } \\
\text { attachments (mediator), } \\
\text { destination satisfaction } \\
\text { (mediator) }\end{array}$ \\
\hline $\begin{array}{l}\text { Chew and Jahari } \\
\text { (2014) }\end{array}$ & Independent & Mediator & Revisit intention & No \\
\hline $\begin{array}{l}\text { Noh and Vogt } \\
\text { (2013) }\end{array}$ & Mediator & Mediator & Visit intention & $\begin{array}{l}\text { Information source usage } \\
\text { (independent) }\end{array}$ \\
\hline $\begin{array}{l}\text { Tavitiyaman and } \\
\text { Qu (2013) }\end{array}$ & Moderator & Independent & $\begin{array}{l}\text { Behavioral } \\
\text { intention }\end{array}$ & $\begin{array}{l}\text { Overall satisfaction } \\
\text { (mediator) }\end{array}$ \\
\hline
\end{tabular}

Source: Own elaboration based on literature

The work of Hamouda and Yacoub (2018) explains the influence of perceived risk, electronic word of mouth (eWOM) and motivations on cognitive and affective destination image and on intention to visit a destination for a potential leisure trip. In the model proposed by the authors, destination image assumes a mediating role. The main findings suggest that perceived risk has a negative influence on cognitive destination image. Whereas, the affective destination image is influenced by eWOM and motivations (knowledge, relaxation and entertainment). The main contribution of the study is to suggest a model which takes into account interrelationships between perceived risk, destination image, visit intention and other variables (eWOM and motivations).

The paper of Kani, Aziz, Sambasivan and Bojei (2017) analyses the antecedents (cultural values and destinations source credibility) and outcomes (destination attachment, destination satisfaction 
and revisit intention) of destination image. The research addresses both the cognitive and affective components of destination image. This work also investigates the moderating role of perceived risk between the destination image of Malaysia and the revisit intention of tourists from West Asia. This would imply that if perceived risk is high, tourists would opt for destinations that are considered to be less risky. The results provide evidence concerning the mediating role of destination image and the moderating role of perceived risk.

The study of Wang (2017) suggests that the judgment that a potential tourist makes regarding the image of a disaster-struck destination, in the previsit stage, plays a critical role in the behavioral intention to travel to that destination. The target population are Chinese tourists who have arrived in Taiwan in order to travel to destinations other than the two disaster-hit spots of SuHua Highway and Alishan Forest Railway. The results demonstrated the importance of the mediating role of perceived image in explaining the intentions of potential tourists to visit destinations affected by the disasters as well as detecting the critical risks influencing the image and, thus recognizing where to direct the actions to modify the negative images.

The work of Chew and Jahari (2014) investigates the effects of risk perceptions on destination image of repeat tourists from Malaysia to Japan in the post-Fukushima disaster context. Besides, the study examines the mediating roles of two destination images, namely, cognitive and affective, on the relations between perceived risk and intention to revisit. The findings show that destination image significantly mediated the relations between two risks, namely, perceived socio-psychological and financial risks, and revisit intention. The research highlights the importance of integrating perceived risk with destination image in the future development of effective positioning strategies in order to mitigate perceived risk, restore image and also improve revisit intention in risky destinations.

The research of Noh and Vogt (2013) simultaneously models information search, perceived risk, and American tourist's intention to visit three destinations, along with cognitive and affective image. In the model, perceived risk and destination image act as mediating variables. The results show that stronger positive cognitive and affective destination images and lower perceived risks for vacationing in a destination positively influenced the intention to visit the countries of interest. Some differences by countries regarding the strength or direction of relations between predictor variables and intention to travel were found (i.e., affective destination image for China, cognitive destination image for Japan, perceived risks for South Korea).

The study of Tavitiyaman and $\mathrm{Qu}$ (2013) examines the influence of destination image and overall satisfaction on the behavioral intention of travellers to Thailand. Besides, it analyses the moderating effect of perceived risk, specifically that of natural disasters, on the relation between destination image, overall satisfaction, and behavioral intention. The population of this study included tourists who visited Thailand after both the SARS outbreak and the tsunami. Travellers with low perceived risk on these natural disasters had a greater tendency for positive destination image, overall satisfaction, and behavioral intention than that of travellers with high perceived risk.

As noted in previous cases, the integrative approach includes different causal models where risk and image interchange the independent, mediating and moderating variables. The assignment of mediating/ moderating roles to the image and perceived risk variables offers an enriching view in order to explain the tourist behavior, due to the possibility of evaluating, more accurately, the way in which the different variables relate to each other. The results of these empirical studies confirm the importance of the integrative approach. The words of Chew and Jahari (2014) are revealing in that respect: "without understanding the type of perceived risks which are specific to a tourist destination and their effects on destination image, general strategies for the improvement of destination image may be less successful in persuading tourists to visit risky destinations" (Chew and Jahari, 2014, p.392). Finally, the use of this approach requires managerial implications to mitigate risk and, therefore, improve both destination image and revisit intention. For these reasons, academics are encouraged to deepen understanding of the interrelations between risk, image and behavioral intention.

\section{Conclusions}

The rise in the number of threats in tourism, as well as the wide coverage of those events by the media, has increased the preoccupation among tourists and destination promoters for safety related to travel. Wars, natural disasters, diseases, terrorism, etc., damage the image of destinations resulting in a consequent drop in visits. The attempt to reduce the impact of these negative events is essential 
for the management of tourist destinations by public authorities and companies' market managers. In this work we intend to analyze the process by which the decision of visiting a destination is the result of evaluating its image, being risk an important factor that has an effect precisely on the destination's image.

The previous analysis is the foundation upon which we propose an innovative classification that links risk and image with behavioral intention. This classification is useful in itself because it allows identifying a new line of research that promises encouraging results by adding valuable information to understand the tourist's behavior. From our perspective, the capacity of a model to explain the behavioral intention increases when perceived risk and destination image are interrelated (integrative approach). This approach allows identifying: a) the types of risk that unsettle tourists the most; b) the image attributes most affected by this preoccupation; and c) approximate information on the intention of the visit in this context.

The review of the literature allows pointing out a number of theoretical and practical contributions within the frame of the integrative approach. It would be worth noting some results of interest for the management of tourist destinations that are mentioned below:

From a theoretical point of view, it is shared the idea of perceived risk and destination image being independent constructs but related in such a way that, the higher the perceived risk is, the worse the destination image becomes (Chew \& Jahari, 2014). The isolated and intrinsic approaches suggested that constructs affect the behavioural intention of tourists. However, the integrative approach suggests that the joint analysis provides a better frame for the understanding of this influence, as it considers that the negative relation between risk and image has an effect on the visit intention. On the other hand, there is also a certain consensus in the need to distinguish between the cognitive and affective components of image (Noh \& Vogt, 2013). When making this distinction, it is that, in general, the affective component has a greater impact on behavioural intention than the cognitive (Hamouda \& Yacoub, 2018).

In the empirical field, there is a high degree of agreement in the importance given to the integration of perceived risk and destination image into the development of effective positioning strategies (Chew \& Jahari, 2014). Destination marketers must be more aware of the role of risk in the formation of destination image. The strategies to improve image will be less successful in persuading visits if the types of specific perceived risks and their impact on image are not understood. Therefore, emphasis is placed on the importance of information and promotion campaigns in which the safety of the destinations is shown considering the identified concerns of tourists. This is a basic task, especially in those destinations that have experienced any kind of threat, disaster or danger (Kani et al, 2017). In these cases, the restoration of image will be achieved, inevitably, by means of mitigating the identified risks, thus making it necessary to publish news and inform about the recovery of those destinations that suffered any kind of threat (Tavitiyaman \& Qu, 2013). Another result that has been found is that the perceptions of risk may vary depending on the characteristics of the traveller (Kani et al, 2017) and the destination (Promsivapallop \& Kanaovakun, 2017). In this sense, the study of this matter in order to formulate marketing strategies adapted to the market segments and specific destinations considered is encouraged (Tavitiyaman \& $\mathrm{Qu}, 2013$ ).

Finally, the usefulness of this work is twofold. Firstly, without being an exhaustive review of the literature, it clarifies the current state of the study of this subject. Second, it gives guidance on the direction of the efforts to be made by the researchers in this field. What is more, this information can be of great use for marketers and policy makers in the management of tourist destinations.

\section{Bibliography}

Adam, I. 2015. Backpackers' risk perceptions and risk reduction strategies in Ghana. Tourism Management, 49, 99-108.

Ahmed, Z. U. 1996. The need for the identification of the constituents of a destination's tourist image: A promotion segmentation perspective. Journal of Professional Services Marketing, 14(1), 37-60.

Alvarez, M. D., and Campo, S. 2014. The influence of political conflicts on country image and intention to visit: A study of Israel's image. Tourism Management, 40, 70-78.

Agapito, D., Oom do Valle, P., and da Costa Mendes, J. 2013. The cognitive-affective-conative model of destination image: A confirmatory analysis. Journal of Travel and Tourism Marketing, 30(5), 471-481.

Baloglu, S., and Brinberg, D. 1997. Affective images of tourism destinations. Journal of Travel Research, 35(4), 11-15. 
Baloglu, S., and McCleary, K. W. 1999. A model of destination image formation. Annals of Tourism Research, 26(4), 868-897.

Baron, R. M., and Kenny, D. A. 1986. The moderator-mediator variable distinction in social psychological research: Conceptual, strategic, and statistical considerations. Journal of Personality and Social Psychology, 51(6), 1173-1182.

Bauer, R. A. 1960. Consumer Behavior as Risk Taking. In R. S. Hancock ed., Dynamic Marketing for a Changing World (389-398). American Marketing Association: Chicago.

Beerli, A., and Martín, J. 2004a. Tourists' characteristics and the perceived image of tourist destinations: A quantitative analysis-a case study of Lanzarote, Spain. Tourism Management, 25(5), 623-636.

Beerli, A., and Martín, J. D. 2004b. Factors influencing destination image. Annals of Tourism Research, 31(3), 657-681.

Bigné, J. E., Sánchez, M. I., and Sánchez, J. 2001. Tourism image, evaluation variables and after purchase behaviour: Inter-relationship. Tourism Management, 22(6), 607-616.

Bigné, J.E., Sánchez, M.I., and Sanz, S. 2009. The functional-psychological continuum in the cognitive image of a destination: A confirmatory analysis. Tourism management, 30(5), 715-723.

Chen, N., and Funk, D. C. 2010. Exploring destination image, experience and revisit intention: A comparison of sport and non-sport tourist perceptions. Journal of Sport and Tourism, 15(3), 239-259.

Chen, J. S., and Hsu, C. H. 2000. Measurement of Korean tourists' perceived images of overseas destinations. Journal of Travel Research, 38(4), 411-416.

Chen, P. J., and Kerstetter, D. L. 1999. International students' image of rural Pennsylvania as a travel destination. Journal of Travel Research, 37(3), 256-266.

Chen, C., and Tsai, D. 2007. How destination image and evaluative factors affect behavioral intentions? Tourism Management, 28(4), 1115-1122.

Cheron, E. J., and Ritchie, J. R. 1982. Leisure activities and perceived risk. Journal of Leisure Research, 14(2), 139-154.

Chew, E. Y. T., and Jahari, S. A. 2014. Destination image as a mediator between perceived risks and revisit intention: A case of post-disaster Japan. Tourism Management, 40, 382-393.

Chon, K. 1990. The role of destination image in tourism: A review and discussion. The Tourist Review, $45(2), 2-9$.

Cohen, E. 1972. Toward a sociology of international tourism. Social Research, 39, 164-182.

Court, B., and Lupton, R. A. 1997. Customer portfolio development: Modeling destination adopters, inactives, and rejecters. Journal of Travel Research, 36(1), 35-43.

Crompton, J. L. 1979. An assessment of the image of Mexico as a vacation destination and the influence of geographical location upon that image. Journal of Travel Research, 17(4), 18-23.

Dann, G. M. 1996. Tourists' images of a destination-an alternative analysis. Journal of Travel and Tourism Marketing, 5(1-2), 41-55.

Dolnicar, S. 2005. Fear segments in tourism. CD Proceedings of the 14th International Research Conference of the Council for Australian University Tourism and Hospitality Education (CAUTHE), 1-5 February 2005, Australia.

Dowling, G. R., and Staelin, R. 1994. A model of perceived risk and intended risk-handling activity. Journal of Consumer Research, 21(1), 119-134.

Echtner, C. M., and Ritchie, J. B. 1991. The meaning and measurement of destination image. Journal of Tourism Studies, 2(2), 2-12.

Fakeye, P. C., and Crompton, J. L. 1991. Image differences between prospective, first-time, and repeat visitors to the Lower Rio Grande Valley. Journal of Travel Research, 30(2), 10-16.

Floyd, M. F., Gibson, H., Pennington-Gray, L., and Thapa, B. 2004. The effect of risk perceptions on intentions to travel in the aftermath of September 11, 2001. Journal of Travel and Tourism Marketing, 15(2-3), 19-38.

Fuchs, G., and Reichel, A. 2006. Tourist destination risk perception: The case of Israel. Journal of Hospitality and Leisure Marketing, 14(2), 83-108.

Fuchs, G., and Reichel, A. 2011. An exploratory inquiry into destination risk perceptions and risk reduction strategies of first time vs. repeat visitors to a highly volatile destination. Tourism Management, 32(2), 266-276.

Fuchs, G. 2013. Low versus high sensation seeking tourists: a study of backpackers' experience risk perception. International Journal of Tourism Research, 15(1), 81-92.

Gallarza, M. G., Saura, I. G., and Garcı a, H. C. 2002. Destination image: Towards a conceptual framework. Annals of Tourism Research, 29(1), 56-78. 
Gartner, W. C. 1989. Tourism image: Attribute measurement of state tourism products using multidimensional scaling techniques. Journal of Travel Research, 28(2), 16-20.

Gartner, W. C. 1994. Image formation process. Journal of Travel and Tourism Marketing, 2(2-3), 191-216.

Gartner, W. C., and Shen, J. 1992. The impact of Tiananmen Square on China's tourism image. Journal of Travel Research, 30(4), 47-52.

Gartner, W. C., and Hunt, J. D. 1987. An analysis of state image change over a twelve-year period (1971-1983). Journal of Travel Research, 26(2), 15-19.

Gibson, H. J., Qi, C. X., and Zhang, J. J. 2008. Destination image and intent to visit China and the 2008 Beijing Olympic Games. Journal of Sport Management, 22(4), 427-450.

Gitelson, R. J., and Crompton, J. L. 1983. The planning horizons and sources of information used by pleasure vacationers. Journal of Travel Research, 21(3), 2-7.

Goodrich, J. N. 1978. The relationship between preferences for and perceptions of vacation destinations: Application of a choice model. Journal of Travel research, 17(2), 8-13.

Gunn, C. A. 1988. Vacationscape: Designing tourist regions (2nd ed.). Van Nostrand Reinhold: New York.

Hallmann, K., Zehrer, A., and Müller, S. 2015. Perceived destination image: An image model for a winter sports destination and its effect on intention to revisit. Journal of Travel Research, 54(1), 94-106.

Hamouda, M., and Yacoub, I. 2018. Explaining visit intention involving eWOM, perceived risk motivations and destination image. International Journal of Leisure and Tourism Marketing, 6(1), 65-82.

Huang, Y., Tseng, Y., and Yiap, L. 2013. Image recovery of the resurrected seashore city-New Orleans, Louisiana. Journal of Coastal Research, 29(2), 430-437.

Hui, T. K., and Wan, T. W. D. 2003. Singapore's image as a tourist destination. International Journal of Tourism Research, 5(4), 305-313.

Hunt, J. D. 1975. Image as a factor in tourism development. Journal of Travel Research, 13(3), 1-7.

Jacoby, J., and Kaplan, L. B. 1972. The components of perceived risk. Advances in Consumer Research, 3(3), 382-383.

Kani, Y., Aziz, Y. A., Sambasivan, M., and Bojei, J. 2017. Antecedents and outcomes of destination image of Malaysia. Journal of Hospitality and Tourism Management, 32, 89-98.

Kaplan, L. B., Szybillo, G. J., and Jacoby, J. 1974. Components of perceived risk in product purchase: A cross-validation. Journal of Applied Psychology, 59(3), 287-291.

Kraemer, H. C., Stice, E., Kazdin, A., Offord, D., and Kupfer, D. 2001. How do risk factors work together? Mediators, moderators, and independent, overlapping, and proxy risk factors. American journal of psychiatry, 158(6), 848-856.

Kozak, M., Crotts, J. C., and Law, R. 2007. The impact of the perception of risk on international travellers. International Journal of Tourism Research, 9(4), 233-242.

Law, R. 2006. The perceived impact of risks on travel decisions. International Journal of Tourism Research, 8(4), 289-300.

Lehto, X., Douglas, A. C., and Park, J. 2008. Mediating the effects of natural disasters on travel intention. Journal of Travel and Tourism Marketing, 23(2-4), 29-43.

Lepp, A., and Gibson, H. 2003. Tourist roles, perceived risk and international tourism. Annals of Tourism Research, 30(3), 606-624.

Lin, Y. H., Wu, C. Y., and Chang, J. 2006. Destination image and visit intention among members of Yahoo!-Taiwan's travel communities: an online survey approach. Tourism Analysis, 11(1), 61-69.

Maser, B., and Weiermair, K. 1998. Travel decision-making: From the vantage point of perceived risk and information preferences. Journal of Travel and Tourism Marketing, 7(4), 107-121.

Milman, A., and Pizam, A. 1995. The role of awareness and familiarity with a destination: The Central Florida case. Journal of Travel Research, 33(3), 21-27.

Mowen, J. C., and Minor, M. 1998. Consumer behavior (5th. ed.). Prentice Hall. Upper Saddle River: New Jersey.

Noh, J., and Vogt, C. 2013. Modelling information use, image, and perceived risk with intentions to travel to East Asia. Current Issues in Tourism, 16(5), 455-476.

Olague, J.T., Flores, C.A. and Garza, J.B. 2017. El efecto de la motivación de viaje sobre la satisfacción del turista a través de las dimensiones de la imagen del destino: El caso del turismo urbano de ocio a Monterrey, México. Investigaciones Turísticas, (14), 109-129.

Perpiña, L., Camprubí, R., and Prats, L. 2017. Destination image versus risk perception. Journal of Hospitality and Tourism Research. doi:10.1177/1096348017704497.

Phillips, W. J., and Jang, S. 2010. Destination image differences between visitors and non visitors: a case of New York city. International Journal of Tourism Research, 12(5), 642-645. 
Pike, S. 2002. Destination image analysis-a review of 142 papers from 1973 to 2000. Tourism Management, 23(5), 541-549.

Pike, S., and Ryan, C. 2004. Destination positioning analysis through a comparison of cognitive, affective, and conative perceptions. Journal of Travel Research, 42(4), 333-342.

Plog, S. C. 1974. Why destination areas rise and fall in popularity. Cornell Hotel and Restaurant Administration Quarterly, 14(4), 55-58.

Prayag, G. 2009. Tourists'evaluations of destination image, satisfaction, and future behavioral intentions-the case of Mauritius. Journal of Travel and Tourism Marketing, 26(8), 836-853.

Qi, C. X., Gibson, H. J., and Zhang, J. J. 2009. Perceptions of risk and travel intentions: The case of China and the Beijing Olympic Games. Journal of Sport and Tourism, 14(1), 43-67.

Quintal, V. A., Lee, J. A., and Soutar, G. N. 2010. Risk, uncertainty and the theory of planned behavior: A tourism example. Tourism Management, 31(6), 797-805.

Ramkissoon, H., Uysal, M., and Brown, K. 2011. Relationship between destination image and behavioral intentions of tourists to consume cultural attractions. Journal of Hospitality Marketing \& Management, 20(5), 575-595.

Reichel, A., Fuchs, G., and Uriely, N. 2007. Perceived risk and the non-institutionalized tourist role: The case of israeli student ex-backpackers. Journal of Travel Research, 46(2), 217-226.

Reisinger, Y., and Mavondo, F. 2005. Travel anxiety and intentions to travel internationally: Implications of travel risk perception. Journal of Travel Research, 43(3), 212-225.

Rittichainuwat, B. N., Qu, H., and Brown, T. J. 2001. Thailand's international travel image: Mostly favorable. Cornell Hotel and Restaurant Administration Quarterly, 42(2), 82-95.

Rittichainuwat, B. N., and Chakraborty, G. 2009. Perceived travel risks regarding terrorism and disease: The case of Thailand. Tourism Management, 30(3), 410-418.

Roehl, W. S., and Fesenmaier, D. R. 1992. Risk perceptions and pleasure travel: An exploratory analysis. Journal of Travel Research, 30(4), 17-26.

Roselius, T. 1971. Consumer rankings of risk reduction methods. Journal of Marketing, 35, 56-61.

Ross, I. 1975. Perceived risk and consumer behavior: A critical review. Advances in Consumer Research, 2(1), 1-20.

Ruan, W. Q., Li, Y. Q., and Liu, C. H. S. 2017. Measuring Tourism Risk Impacts on Destination Image. Sustainability, 9(9), 1501.

Ross, G. F. 1993. Ideal and actual images of backpacker visitors to Northern Australia. Journal of Travel Research, 32(2), 54-57

Russell, J. A., and Pratt, G. 1980. A description of the affective quality attributed to environments. Journal of Personality and Social Psychology, 38(2), 311-322.

San Martín, H., and Rodríguez del Bosque, I. A. 2008. Exploring the cognitive-affective nature of destination image and the role of psychological factors in its formation. Tourism Management, 29(2), 263-277.

Schiffman, L. G., and Kanuk, L. L. 1991. Communication and consumer behavior. Consumer Behavior, 2, 268-306.

Schroeder, T. 1996. The relationship of residents' image of their state as a tourist destination and their support for tourism. Journal of Travel Research, 34(4), 71-73.

Simpson, P. M., and Siguaw, J. A. 2008. Perceived travel risks: The traveller perspective and manageability. International Journal of Tourism Research, 10(4), 315-327.

Sönmez, S. F. 1998. Tourism, terrorism, and political instability. Annals of Tourism Research, 25(2), 416-456.

Sönmez, S. F., and Graefe, A. R. 1998a. Determining future travel behavior from past travel experience and perceptions of risk and safety. Journal of Travel Research, 37(2), 171-177.

Sönmez, S. F., and Graefe, A. R. 1998b. Influence of terrorism risk on foreign tourism decisions. Annals of Tourism Research, 25(1), 112-144.

Sönmez, S., and Sirakaya, E. 2002. A distorted destination image? The case of Turkey. Journal of Travel Research, 41(2), 185-196.

Stone, R. N., and Grønhaug, K. 1993. Perceived risk: Further considerations for the marketing discipline. European Journal of Marketing, 27(3), 39-50.

Tasci, A. D., and Gartner, W. C. 2007. Destination image and its functional relationships. Journal of Travel Research, 45(4), 413-425.

Tasci, A. D., Gartner, W. C., and Tamer Cavusgil, S. 2007. Conceptualization and operationalization of destination image. Journal of Hospitality and Tourism Research, 31(2), 194-223. 
Stylos, N., Bellou, V., Andronikidis, A., and Vassiliadis, C. A. 2017. Linking the dots among destination images, place attachment, and revisit intentions: A study among British and Russian tourists. Tourism Management, 60, 15-29.

Tavitiyaman, P., and Qu, H. 2013. Destination image and behavior intention of travelers to Thailand: The moderating effect of perceived risk. Journal of Travel and Tourism Marketing, 30(3), 169-185.

Tsaur, S., Tzeng, G., and Wang, K. 1997. Evaluating tourist risks from fuzzy perspectives. Annals of Tourism Research, 4(24), 796-812.

Um, S., and Crompton, J. L. 1992. The roles of perceived inhibitors and facilitators in pleasure travel destination decisions. Journal of Travel Research, 30(3), 18-25.

Wang, H. Y. 2015. Determinants hindering the intention of tourists to visit disaster-hit destinations. Current Issues in Tourism, 20(5), 459-479.

Wang, C. Y., and Hsu, M. K. 2010. The relationships of destination image, satisfaction, and behavioral intentions: An integrated model. Journal of Travel and Tourism Marketing, 27(8), 829-843.

Woodside, A. G., and Lysonski, S. 1989. A general model of traveler destination choice. Journal of Travel Research, 27(4), 8-14.

Xu, J., Chan, T. L., and Pratt, S. 2017. Destination Image of Taiwan From the Perspective of Hong Kong Residents: Revisiting Structural Relationships Between Destination Image Attributes and Behavioral Intention. International Journal of Hospitality and Tourism Administration, 1-23.

Yang, E. C. L., and Nair, V. 2015. Tourism at risk: A review of risk and perceived risk in tourism. Asia-Pacific Journal of Innovation in Hospitality and Tourism, 3(2), 1-21.

Zhang, H., Fu, X., Cai, L. A., and Lu, L. 2014. Destination image and tourist loyalty: A meta-analysis. Tourism Management, 40, 213-223.

\section{Notes}

1 The study of Perpiña et al. (2017) asserts that the attributes that separately assess cognitive image and risk constructs frequently overlap so they recommend the elimination of duplicate assessments.

Authors review a total of 46 works.

142 reviewed by Pike (2002) and 39 by Tasci \& Gartner (2007).

Mediating variables explain how and why a certain effect is produced, whereas moderating variables explain when or in what subjects/conditions certain effects will occur (Kraemer, Stice, Kazdin, Offord \& Kupfer, 2001). The literature establishes criteria to distinguish, based on data, whether a variable is either mediating or moderating. To study this topic in depth, see the works of Baron and Kenny (1996) and Kraemer et al. (2001). 